the strong support for energy-efficiency measures is that they give people more money to spend, not necessarily to save.) According to another rebound effect, if fuel-efficiency regulations for vehicles in the United States and Europe curb petrol consumption, that should suppress the price of oil and encourage its use in other sectors or countries.

Last week, the Breakthrough Institute, based in Oakland, California, released a strongly phrased analysis that argues that these rebound effects are so large they could overwhelm many or all of the gains from energy-efficiency measures (see go.nature.com $/ \mathrm{m} 5 \mathrm{ky} 3 \mathrm{~g}$ ). The advocacy group calls for massive investment in the research and development of low-carbon energy to counter what it says are overoptimistic assumptions about what can be accomplished through greater efficiency.

This is controversial stuff, and also frustrating. These are fundamentally interesting questions, but part of a debate that circles on itself. Was it really fair for Jevons to blame coal's expansion and technological diffusion on efficiency? Do people actually save money when their energy bills go down, or do they spend more money? Is the spread of refrigerators around the world purely because they have become more energy efficient, or because they are useful devices that keep food fresh for days on end? Is it the energy bill or the sticker price that people worry about when buying an appliance? And isn't technological diffusion and energy access throughout the world a good thing?

The rebound effects need to be considered, but they do not have to be viewed as paradoxical: they amount to economic expansion. Indeed, some researchers think that energy efficiency itself is a fundamental driver of economic growth, freeing up resources that can
"The world cannot solve all of its energy and climate woes with energy efficiency alone." be used for other things, the deployment of low-carbon energy among them.

Despite its concerns about the rebound effect, the Breakthrough Institute argues that energy efficiency should nonetheless be pursued for exactly these reasons. Encouragingly, the discussion prompted by its report has led to plans from academics and industry experts on all sides of the debate to meet to wade through these issues.

The debate indicates that there must be deeper study of what energy efficiency could do if systematically deployed across an entire economy. The world cannot solve all of its energy and climate woes with energy efficiency alone; low-carbon energy technologies must be developed as well. But there seems to be no fundamental physical or economic reason that countries can't decrease their overall energy consumption while maintaining growth, and thus put the ghost of Jevons to rest.

\section{Rights for all}

\section{Scientists should push for fair treatment of Turkish academics arrested on little evidence.}

$\mathrm{E}$ arlier this month, a Turkish court acquitted the sociologist Pinar Selek on terrorism charges - the third time she has been cleared of causing a 1998 explosion at an Istanbul spice market that killed seven people. Selek's real crime, in the eyes of the Turkish government, seems to have been contact with Kurdish separatist groups as part of her academic research. Prosecutors have again appealed the not-guilty verdict, to howls of outrage from human-rights groups in Europe, which is watching Turkey's conduct in the case with interest as the nation seeks membership of the European Union (EU).

A less-scrutinized and less-supported cause are the dozen or so Turkish academics arrested - among hundreds of others - as part of a government crackdown on 'deep-state networks'. In the past, these are said to have violently targeted those whom they consider to be Turkey's enemies, including Kurdish separatists. Turkish police say that they have uncovered a tightly controlled, hierarchical organization - called Ergenekon - that conspires to destabilize the government through political violence and pave the way for a military coup.

The government frames its Ergenekon investigation as a step towards democratic reform, but detractors say it has also been used as an excuse to round up and silence government critics, particularly vociferous defenders of secularism in politics and education.

An independent analysis of the investigation by the Istanbul-based analyst Gareth Jenkins says that many of those arrested seem to be linked to one another by little more than their opposition to Islamic conservatism and the ruling Justice and Development Party (AKP). That certainly describes the arrested academics - most of whom hailed from the conservative secular elite - including several university rectors who had decried attempts to lift the headscarf ban in Turkish universities, and criticized, for example, the appointment of AKP supporters to key academic positions, such as in the government's science-funding agency TÜBİTAK.

Most of the arrested academics have been released on bail, but two are still being held: Mehmet Haberal, the US-trained rector of Baskent University in Ankara, who pioneered transplant surgery in Turkey, and physician Fatih Hilmioğlu, former rector of İnönü University in Malatya.

The two have now been detained for almost two years, and there is no sign that they will be released, or have their trials heard, any time soon. Turkish law allows indicted individuals to be kept in long-term detention only if there is a danger that they might either destroy evidence or flee. Supporters say that both scientists are being treated for poor health and neither danger applies.

Questions have been asked on their behalf. In December 2009, Carol Corillon, executive director of the US National Academies' committee on human rights, expressed concern about the arrest of the academics in University Values, an electronic bulletin. And last year, the Turkish Academy of Sciences raised the detentions with Turkish President Abdullah Gül, who said he could not interfere with the independent courts.

Mostly, however, silence rules. The huge Ergenekon trial is moving very slowly, and those out on bail have been warned not to prejudice its outcome by discussing their cases publicly. The investigation has engendered an atmosphere of fear in universities. Academics are keeping their heads down and trying to enjoy the genuine attempts that Turkey is making to raise its science base towards EU norms. TÜBİTAK is also keeping quiet, afraid of further charges of political interference in scientific matters, such as it attracted in 2009, when it pulled the Darwin-celebratory cover of its popular-science magazine Bilim ve Teknik and demoted its editor (see Nature 458, 259; 2009).

Meanwhile, most human-rights groups have proved less keen to jump to the defence of those on the political right than those on the left, including Selek. Jenkins' report did stress that the Ergenekon investigation successfully identified some deep-state operatives, probably involved in political violence. And phone-tap transcripts have exposed unpleasant and antidemocratic right-wing sentiment among some of the indicted individuals.

But according to the European Convention on Human Rights, everyone has the right to a fair trial in a reasonable time. The Turkish government needs to feel the world's eyes on the actions of its judiciary. And the international scientific community should spread the word on the indicted and detained academics, and monitor how fairly their cases are handled. The last thing Turkish scientists need $\rightarrow$ NATURE.COM To comment online, click on Editorials at: go.nature.com/xhunqu right now - as research investment is growing but the legal and administrative framework is not always keeping up - is to be afraid to criticize how their promising scientific landscape is developing. 